\title{
Occupational safety and health in garment enterprises in Vietnam - the corporate social responsibility to employees
}

\author{
Bui Thi Kim Thoa \\ Thuongmai University \\ Kimthoa0412@gmail.com
}

\begin{abstract}
By making statistics and analyzing the data provided by the Department of Occupational Safety and Health, ILO\&IFC, and other sources, the author shows the fact that implementing occupational safety and health in enterprises is a part of implementing corporate social responsibilities to employees, occupational safety and health in enterprises is an issue, which has the most violations in labor matters. They are mainly concentrated in 4 groups: worker protection, OSH management system, emergency response, chemicals and hazardous material, with very high non-compliance rates, $93 \%$, $82 \%, 74 \%, 68 \%$ respectively. Through real analysis, the author gives some suggestions to improve the implementation of occupational safety and health.
\end{abstract}

Index Terms-occupational safety and health, corporate social responsibility, garment enterprises.

\section{INTRODUCTION}

$\mathrm{O}$ CCUPATIONAL safety and health (OSH) in an enterprise is the workers' right to safety, which is also an important part of the corporate social responsibility to employees, except the other part of the corporate social responsibility to employees, including Freedom of assembly and collective labor agreement; Discipline and working time; Remuneration and management system. Corporate social responsibility to employees has received much attention from researchers because of its increasingly important role for each business. Implementing corporate social responsibility to employees is the protection of workers' rights, first of all respecting and ensuring the basic rights of employees, including the right to safety. However, in Vietnam, many garment enterprises have not let employees work in an environment with many unsafe and harmful hazards by neglecting the $\mathrm{OSH}$. Textile and garment industries are considered as one of the highest OSH risks, ranking 9th out of 11 industries occupations with high OSH risks. That is the reason for many accidents in the garment industry. According to statistics of the Department of Occupational Safety, for 5 consecutive years (2016-2020), the textile and garment industry is classified as an industry with deadly occupational accidents, accounting for $5-7 \%$ of the whole country. Implementing OSH is not only fulfilling corporate social responsibilities to employees it is also a requirement of international integration to raise the level of OSH compliance in the enterprise to international standards, to have long-term business cooperation with inter- national partners. However, Vietnamese garment enterprises still have many violations of OSH regulations, so, the author hopes to give a description of the compliance with the law on occupational safety and hygiene in garment enterprises, thereby analyzing, discussing and proposing some suggestions for improving compliance with the law on OSH, ensuring the basic rights of employees working. This Study includes 5 main parts: introduction, literature review, proposed work, result and discussion, conclusion and suggestions.

\section{Literature Review}

Corporate social responsibility and corporate social responsibility to employees by implementing OSH in the enterprise are valuable for researching, therefore there are lots of studies about this topic.

Bowen in research named "Social Responsibility of Businessman" has defined CSR as the obligation of business people to pursue policies, make decisions or perform a series of socially desirable activities in terms of goals and values. After that, there was a strong development in the concept of social responsibility [1]. Elkington suggested that there are three sustainable factors in the operation of an enterprise showing the 3Ps such as people, the earth (planet), and profit for the enterprise's sustainable development [2]. On the topic of corporate social responsibility to employees, [3-5] pointed out that, " The company needs to commit to ensuring the health and safety of employees" is a part of implementing corporate social responsibility to employees. The same is shown in the studies [6-9]. The role of implementing OSH - CRS to employees to create conditions for the sustainable development of the enterprise as indicated in many studies such as ILO [10-15]. In reality, there are many enterprises that refuse to implement $\mathrm{OSH}$ measures, violate OSH and OSH legislation and ignore sustainable benefits from OSH because they have to pay an amount of money to maintain safe working conditions.

Through other research, the author found that an in-depth study of the occupational safety and health situation in garment enterprises in Vietnam is necessary.

Methodology

In this study, the author used the documentary research method. The secondary data is collected information statis- 
tics on occupational safety and hygiene in garment enterprises in Vietnam such as the data of accidents, occupational diseases, number of legislation violations on occupational safety and health from the studies, report of ILO, IFC, Department of Occupational Safety, Department of Vietnam Textile Union... to analyze and give assessments about the implementation of occupational safety and health in garment enterprises in Vietnam for 05 years and find out the causes, consider the factors affecting, thereby proposing some suggestions to improve the implementation of occupational safety and health in garment enterprises in Vietnam.

\section{Proposed Work}

Many researchers defined corporate social responsibility. According to experts of the Business Council for Sustainable Development (2002), "Social responsibility is the commitment of enterprises to business ethics and contributes to sustainable development, improving the quality of life for employees and their families, local communities and society at large"; In 2003, experts from the World Bank said that: "Social responsibility of enterprises is the commitment of enterprises to contribute to sustainable economic development, through activities to improve the quality of life of employees and their family members, for the community and for the whole society in a way that is beneficial to businesses as well as the general development of society". Thus, most researchers agree that part of corporate social responsibility to employees is to take care of the lives of employees.

According to Dinh Thi Huong, "implementing social responsibility for employees includes all activities to realize the commitments of enterprises to employees, thereby improving the quality of life for employees as well as ensuring the development of employees. sustainable development of enterprises" [5], which includes constantly improving working conditions, ensuring occupational safety and hygiene for employees in the enterprise.

The term "occupational safety and health", that refers to a multidisciplinary field concerned with the safety, health and welfare of workers in the workplace [16]. "Safety" and "health" are two closely related categories because they can arise at the same time in the same space, It means the worker could be unsafe and have diseases in the workplace in working process. However, we clearly differentiate "safety" and "health" through the way in which hazardous factors and harmful factors in working conditions affect people; Occupational safety refers to measures to help reduce the "dangerous" factor that causes "occupational accidents", emphasizing "incidents" that occur "unexpectedly", while occupational hygiene means to say to measures to help prevent and avoid "harmful" factors, which affect workers "slowly" over time and cause "occupational diseases". According to the ILO, OSH is defined as "the sci- ence of the anticipation, recognition, evaluation and control of hazards arising in or from the workplace that could impair the health and well-being of workers, taking into account the possible impact on the surrounding communities and the general environment". Occupational safety and health are the activity of many different subjects, each with different roles, their occupational safety and health activities are also different. With the science of occupational safety and health, they research scientifically to come up with measures, protective means or rules to prevent occupational accidents and occupational diseases. Therefore, occupational safety and health in an enterprise is understood as all the measures that enterprises take to prevent occupational accidents and occupational diseases from dangerous and harmful working conditions, to ensure safety and health for workers.

In the period of industrialization, modernization and international economic integration, Vietnam has ratified ILO conventions on occupational safety and health, including: Convention 148 on the protection of workers against occupational diseases. occupational risks due to air pollution, noise and vibration in the workplace (1977); Convention 155 on occupational safety and health and working environment, Recommendation 164 on Occupational safety, health and working environment (1981); Convention 170 on safety in the use of chemicals at work, Recommendation No. 177 on safety in the use of chemicals at work (1990); Convention 183 on Maternity Protection (2000)... and Vietnam is also completing the national legislation on OSH by promulgating legislation to manage $\mathrm{OSH}$ in enterprises, including Law on Occupational Safety and Health (2015); Law on Fire Prevention and Fighting (2001); Decree 39/2016/NDCP guiding the Law on Occupational Safety and Health, Decree 88/2020/ND-CP guiding the Law on Occupational Safety and Hygiene on occupational accident and disease insurance mandatory ... Through the study of ILO conventions, ILO recommendations, national laws and a number of documents on occupational safety and health in enterprises such as: fundamental principle of OSH [17]; Principles of Occupational Safety Management [18] and textbook on occupational safety and health [19], the author recognise that occupational safety and health in enterprises include 7 basic contents, which are:

\section{(i) Building an OSH management system}

The occupational safety and health management system in an enterprise is defined as a network of involved factors. These factors include person and their responsibilities, relationships between the position in the system, activities, processes, line of action, and resources. Thus, building an OSH management system means setting up a management apparatus, regulating the operation of parts in the management apparatus, stipulating the responsibilities and powers of positions, developing a process to manage OSH, and defining the relationship between departments. On the ether 
hand, the enterprise must also make a general assessment of the occupational safety and health situation to have an overview to build a system of regulations, safety rules, plans for the implementation of occupational safety and health.....and at the same time, to record cases of occupational accidents and diseases to learn from experience.

In order for the OSH management system to work effectively, the regulations on the rights, obligations, resources of each element in the apparatus could be clearly defined; an operation process should be built to manage the OSH system; a large number of employees clearly understand their roles, positions, duties.

\section{(ii) Chemical and hazardous materials safety}

Chemical safety is very important, because if chemical safety is not ensured, its consequences will not only affect the health and lives of workers but also greatly affect the environment. Chemical and hazardous materials management includes: the employer stores the chemicals and hazardous materials used at the workplace properly; appropriately labeled chemicals and hazardous materials; the employer has used records for hazardous materials; employers perform activities to evaluate, supervise, prohibit, and moderate workers' exposure to hazardous substances; workers work with hazardous materials are trained effectively; employees are provided adequate washing facilities and cleaning materials in case of exposure to hazardous chemicals.

\section{(iii) Worker Protection}

Employees must be provided personal protective equipment (PPE) free of charge to protect them from workplace hazards such as chemicals, noise, air pollution, sharp objects, eye injuries or burns. Employees must be provided personal protective equipment (PPE) free of charge to protect them from workplace hazards (chemicals, noise, air pollution), vulnerable body areas (eyes, head, hands), sharp objects, burns. Employees also must be trained to use the PPE, and employers must remind and monitor workers of their duties to use it at the workplace. PPE are gloves, glasses, helmets, protecting clothes, masks...they protect a part of body safety.

The equipment in the workplace such as machines, shelves for finished products, semi-finished products, tools, wires, etc. must be arranged logically with ergonomic principles. If workers trust that they face a coming and serious danger, they could deny working without punishment for doing so.

In Vietnam, the government enacts the OSH law and Vietnam standard to force employers to provide PPE for workers.

\section{(iv) Ensure a safe working environment;}

The workers must ensure that the workplace environment is monitored and controlled at appropriate levels of the ambient factors in the workplace such as temperature, ventilation, humidity, noise, and lighting, as regulated by the national OSH law and other related regulations. If one of the ambient factors in the workplace surpassed the allowable limit, it will cause harm to workers' health. Depending on their intensity, they cause immediate injuries (cause occupational accidents) or cause health problems through long-term exposure (cause occupational diseases). Ensuring a safe working environment is the responsibility of the employers and is guaranteed to implement by national legislation.

(v) Occupational disease management and medical services.

Occupational disease management means that the employers monitor the health of each employee through their healthy report. Employers need to have periodic health checks for the workers to ensure that they are healthy enough to meet current job demands and detect occupational diseases early.

In addition, the employees could be injured in the workplace, so the employers must ensure to address safety and health risks to employees. That is the reason why the workplace have needed onsite medical facilities and staff; the employer makes sure that there are complete of readily reachable first aid supplies suit for the number of workers, also, the employees are trained for first-aid to respond to emergencies.

\section{(vi) Emergency preparedness}

Emergency preparedness is an employer's preparation for emergencies, such as problems related to fire, problems related to electrical incidents causing fire and explosion, etc. For Emergency preparedness, the employers are required to be fully equipped with fire alarms, emergency extinguishing equipment, warning signs, emergency exits (require to the width of the emergency exit, the number of exits).

In order to face an emergency, the employer is required to train employees in basic knowledge including how to recognize the fire alarm, how to use extinguishing equipment, use the emergency exit, ect, and the employer must conduct periodic drills for emergencies.

(vii) Welfare facilities in $\mathrm{OSH}$

The welfare in OSH for employees includes: the workplace has adequate accessible toilets for employees; the workplace has sufficient hand washing soap and hand sink; the worker is supplied enough free safe drinking water. These are basic human needs, especially the need for drinking water, the need for a clean toilet.

\section{Result and Discussion}

Vietnam is currently in the top 5 countries in terms of global garment exports, of which the majority of goods are exported to the United States (46.1\%), Europe (13.7\%), Japan. 12.5\%) and Korea (9.9\%) [11]. In 2019, Vietnam has more than 6,000 enterprises operating in the garment sector with nearly 2.7 million people, it's about 4,200 garment enterprises, most of them are the garment export (CTM - cut make - trim) [11]. The employees in garment enterprises are mainly unskilled workers, with low qualifications. The num- 
ber of primary workers and ones with less than 3 months of vocational training is $81.2 \%$ [20]

Since becoming a member of free trade agreements, Vietnam has been improving its national labor laws to bridge the gap between international labor standards and national labor laws. The government makes a plan to extend the worker's rights like improving the working condition regulation to gain the tax offer and trade opportunity from the new general FTAs such as CPTPP, EVFTA.

Although, for 2016-2020, the accident number in the garment sector at a high level. It reached a peak In 2018 with 103 accidents and 111 deaths. In 2020, this number was decreased by $50 \%$. However, within 5 years, the textile and garment industry has always been classified as one of the industries with a high number of occupational accidents. It shows that the risks to get accidents in the garment sector still at an alarming rate. In addition, the statistical reports on occupational accidents provided by the Department of Occupational Safety are just incomplete figures. The annual report on occupational accidents states that the reporting rate of enterprises to the Department of Labor - Invalids and Social Affairs is still low. In 2019, it's about 5.9\% of enterprises reported, in 2020 , the one is about $5.47 \%$. It shows that the actual number could be much larger than the reported number.

The database on occupational diseases is also very lacking and incomplete. In the garment industry, early detection of occupational diseases has not been fully and seriously implemented. According to Mr. Nguyen Hong Chien, Head of Propaganda Department of Vietnam Textile Union, in 2019, there was 116,370 out of 130,427 workers received periodic health checks. According to reports from 118 Textile and Garment unions, no cases of occupational diseases have been detected. However, the number of members at trade unions is extremely lower than the total number of employees in the Textile and Garment industry (2.7 million employees in the Textile and Garment industry). According to the Ministry of Health, the current periodical health checking only stops at classifying health and detecting some common diseases. In fact, survey data on 1,000 garment workers aged 25-35 at 3 enterprises in Binh Duong, Ho Chi Minh City and Dong Nai of the Institute of Public Health Hygiene of Ho Chi Minh City showed that there was $93 \%$ of workers suffer from fatigue after work; $47 \%$ of workers suffer from general fatigue; $16.7 \%$ of workers suffer from strong headache; $15.1 \%$ of workers showed signs of burnout; $80 \%$ of muscle and joint pain in the waist, neck and shoulder area. These statistics show that many textile and garment business owners (especially those without a trade union, small businesses) are neglecting the rights of employees, especially in improving working conditions, taking care of employees' health, in order to prevent occupational accidents and control occupational diseases for employees.

The occurrence of occupational accidents and neglect of workers' health are the result of incompliance OSH regula- tion of garment enterprises. According to statistics from the Vietnam better work program, the rate of garment enterprises violating regulations on occupational safety and health is the highest among all labor violations.

Table 1: Violations Of Regulation On Osh By Garment Emterprises Participating In Better Work

\begin{tabular}{|c|c|c|}
\hline Violations & $\begin{array}{c}2017 \\
(n=257)\end{array}$ & $\begin{array}{c}2019 \\
(n=331)\end{array}$ \\
\hline $\begin{array}{l}\text { Building an } \mathrm{OSH} \text { management } \\
\text { system }\end{array}$ & $66 \%$ & $82 \%$ \\
\hline $\begin{array}{l}\text { Chemicals and hazardous } \\
\text { materials }\end{array}$ & $73 \%$ & $68 \%$ \\
\hline Worker protection & $89 \%$ & $93 \%$ \\
\hline Working environment & $21 \%$ & $15 \%$ \\
\hline $\begin{array}{l}\text { Occupational disease management } \\
\text { and medical services }\end{array}$ & $51 \%$ & $51 \%$ \\
\hline Emergency preparedness & $80 \%$ & $74 \%$ \\
\hline Welfare facilities & $58 \%$ & $43 \%$ \\
\hline
\end{tabular}

(Source: compiled from the report of the Better work program in Vietnam)

\section{Building an OSH management system in the enterprise}

The issue of building an occupational safety and health system is specified in the OSH law (2015) and Decree $39 / 2016$ ND-CP. However, there is a significant increase in violations from $73 \%$ in 2017 to $82 \%$ in 2019 . The cause is believed to be due to a change in the regulations on standards of the person in charge of occupational safety and health position. In fact, these factories have not enough employees of the OSH department (compared to the size of the factory) or the employees are not qualified to undertake this work as prescribed. As required by the new OSH Law, the OSH officers have to meet certain criteria on educational background and experience.

Similarly, Vietnamese law also requires factories to establish an OSH collaborator's network, which more than a quarter of factories still fail to do adequately.

The OSH National law raises standards for OSH positions and medical staff is expected to help the OSH system in enterprises work effectively.

\section{Chemical and hazardous materials management}

Chemical safety in enterprises is specified in the OSH law and the chemicals law. In recent years, the chemical safety has improved, specifically, there was reduce of violation rate from $73 \%$ in 2017 to $68 \%$ in 2019 . However, the violation rate is still high. The main violations in chemical safety include: not labeling chemicals (44\% of enterprises violate); the number of violations on storage was $33 \%, 34 \%$ of enterprises did not train employees in the use and storage of chemicals, $25 \%$ of enterprises did not fully record the number of chemicals used.

\section{Labor protection}

The provision of labor protection equipment in garment enterprises is quite specific and detailed in Circular 
04/2014/TT-BLDTBXH. However, in the matter of labor protection, there are many garment factories in the Better Work program that do not pay enough attention to separate occupational safety and hygiene requirements for different types of work. There are stricter requirements on several positions, such as people working at height, people working with cutters, presses, irons, dryers, etc. All of these jobs require workers get certifications for using machines. Similarly, the worker is inadequate PPE provision or low-quality PPE is popular. In addition, workers often do not comply with regulations on the use of protective equipment. They don't regularly use PPEs such as gloves, goggles, and carbon masks, and they pull out or deviate the protective shield of the sewing machine to see easier. It is the lack of responsibility of employers and employees in the work of occupational safety and health that leads to a very high rate of noncompliance, there are respectively $47 \%, 35 \%$, and $39 \%$ of factories observed non-compliance in issues including jobs with strict OSH requirements, use of PPEs, and safe operation of machinery, [11]. Non-compliance with electrical safety has also taken place for a long time. There is $37 \%$ of observed factories are poorly in installing and maintaining electrical wires, switches, and plugs.

Ensure a safe working environment

This is the issue with the fewest recorded violations in occupational safety and health issues in garment enterprises participating in the better work program. The rate violations in 2017 and 2019 are respectively $21 \%$ and $15 \%$. The main environmental violations in garment enterprises are related to noise and dust.

\section{Ensure emergency response}

In several years, the locking of the exit doors no longer occurs, but another phenomenon occurs in more than half of the surveyed factories, which is the situation where the exit is blocked by goods, materials, even machines. Along with that issue, poor quality fire fighting equipment and alarm systems and lack of coordination in the network of occupational safety and health workers are also the problems of more than half of the surveyed factories.

The highest rates of incompliance in emergency preparedness include storage of flammable materials (12\%); properly installing and maintaining electrical cords, switches, plugs and electrical appliances (21\%); indication of emergency exits $(41 \%)$; emergency exits are locked, blocked or inaccessible during business hours (51\%).

Fire fighting equipment and fire alarm systems are not of good quality, accounting for $44 \%$ of surveyed factories. Although the awareness of fire safety has increased, the problem of ensuring a suitable fire protection system is still not well implemented, many factories do not have enough fire alarm systems, besides, they also do not periodically check and maintain this fire detection and alarm system.

\section{Conclusion And Suggestions}

Statistics on occupational accidents and occupational diseases of garment enterprises in Vietnam show that serious occupational accidents in garment enterprises are still very large, in the past 5 years, garment enterprises are still the one of the types of enterprises with the highest rate of death from occupational accidents and is classified in the group of industries with high risk of occupational accidents. There are no specific statistics on occupational diseases in garment enterprises in Vietnam, however, the early detection of occupational diseases has not been taken seriously. In addition, garment enterprises that violate regulations on OSH also account for a large proportion of all contents of OSH.

Garment is a potential industry, making a great contribution to the national GDP (from 10-15\% of GDP), and also creating many jobs for the economy. But from the study of statistics on occupational accidents, diseases and the number of violations of regulations on $\mathrm{OSH}$ in garment enterprises in Vietnam, shows that the implementation of OSH in garment enterprises still has many problems that need to be improved to implementing responsibilities, ensuring the occupational safety and health rights of employees, towards sustainable development, the author would like to give some suggestions as follows:

For garment businesses

- Be aware of the role of OSH

Implementing OSH has been costly in the short-term, but employers gain in the long-term, that include: protecting and enhancing brand image and brand value; helping the employee maximize their productivity; helping employees adhere to the business; building a more competent, healthier workforce for enterprises; reducing business costs and disruption because of cutting down accidents; enabling businesses to meet customers' OSH expectations, and encouraging them to stay longer in active life.

Risks at work should be reduced to a minimum, because they may damage the health of employees, losses the cost and reputation for companies, and damage to economies. Therefore, employers need to plan to identify, assess the dangers and risks in the workplace and implement preventive measures for employees. It is necessary to build into a system of risk control and prevention and regularly evaluate and improve this system.

Every enterprise can enjoy worthy of attention benefits by investing in OSH. Simple improvements in OSH can increase competitiveness, profitability and increase the motivation of employees. The performance of an OSH management system provides an effective framework to prevent or minimize accidents and ill health, help enterprises developing in sustainability.

- Promotes training on OSH for employees

The training OSH is really important because the purpose of training is to raise employees' awareness of the role of oc- 
cupational safety and health in the health and life of employees, provide them with safe working knowledge, lead to safe and health-oriented behavior. Training is seen as a vital part of prevention measures which has eliminated risks and prevented them from the causing source.

- Strengthen communication on OSH for employees

The data in part 4 is shown that the awareness of employees about risk is low, they are ready to take off the protective equipment to get convenience instead of their safety. The reason is the lack of knowledge about safety. To improve this issue, employers need to promote communication of the information about OSH to employees to raise awareness of safety for workers.

For state management agencies

- Strengthen the inspection, examination and handling of violations in $\mathrm{OSH}$ at garment enterprises.

The implementation of occupational safety and health in enterprises needs to be closely and regularly monitored and checked by government management agencies to ensure that enterprises comply with the law on OSH.

The OSH inspectors will note the issues that are not regulated by the law, the problems that are still inadequate to propose to the superiors in amending the laws. In addition, the occupational safety and health inspectors also advise employers and employees on measures to overcome shortcomings in the implementation of OSH at enterprises so that $\mathrm{OSH}$ practices in enterprises are effective. The reality showed that the OSH improving suggestion is important to help the enterprise in building the OSH system.

- Strengthen communication and education on OSH legislation for employees and employers.

The employees in garment enterprises are mainly low qualifications so they almost lack law knowledge. They do not aware of their duties and rights in OSH. The government needs to select suit method in communication for low qualification workers. With the worker, seminar or book is not suit. They will be impressed with a short phrase, an image, or a short story. The government could research to find out an effective way to give information to them.

- Increase the level of OSH's penalty to deter OSH violations.

Currently, the level of administrative penalties for violations of the law on occupational safety is still very low. In fact, the administrative fine level of enterprises is not enough of a deterrent, so violations of the law on occupational safety and hygiene still take place at a high rate.

The Government should research to increase the appropriate fines and expenditures and consider using forms such as suspension of operations or deprivation of business license.

- Increasing the supervisory role of OSH implementation in garment enterprises by unions.

Trade unions are organizations that represent and protect the interests of workers. According to the provisions of national law, trade unions have the duty to supervise the im- plementation of occupational safety and health of enterprises. However, in Vietnam, trade unions are mostly parttimers, receiving salaries from employers. This makes unions vulnerable and dependent on employers.

The State needs to strengthen the protection of the supervision rights of trade unions and workers in order to effectively use this monitoring channel.

For workers

- Actively improve their understanding of their rights and responsibilities in OSH: In relation to employers, workers are often seen as weaker, however, this does not mean that workers can not protect their basic rights. The law has specific provisions to protect workers to a certain extent, importantly, the workers themselves. They need to be more proactive in recognizing their rights and taking action to protect them. In order to do that, they first need to actively increase their understanding of labor laws and promote the activities of workers' unions.

\section{REFERENCES}

[1] Bowen, R. H, "Social responsibility of the businessman", Harper \& Row, New York., 1953

[2] Elkington, "Cannibals with Forks: The Triple Bottom Lines of $21^{\text {st }}$ century Business". Capstone Publishing Limited, Oxford, 1999

[3] Lorraine Sweeney, "A Study of Current Practice of Corporate Social Responsibility (CSR) and an Examination of the Relationship Between CSR and Financial Performance Using Structural Equation Modelling (SEM)", 2009

[4] United nations, "The corporate responsibility to respect human rights". An Interpretive Guide - New York and Geneva, 2012

[5] Đinh Thị Hương, "Trách nhiệm xã hội đối với người lao động của các doanh nghiệp may Việt Nam", Đại học Thương mại, 2019

[6] Beresford D. and Freeman S, "Companies Increase Social Responsibility Disclosure Management Accounting", Journal of Business Ethics, 51-5, 1979

[7] Clarkson M, "A stakeholder framework for analyzing and valuating corporate social performance". The Academy of management review 20(1), 92-117, 1995.

[8] Robertson D. and Nicholson N, "Expressions of Corporate Social Responsibility in UK Firms", Journal of Business Ethics 15(10), 1095-106, 1996

[9] Ashridge, "Catalogue of CSR Activities: A Broad Overview Ashridge Centre for Business and Society", Hertfordshire, 2005

[10] ILO, "Cải thiện An toàn và Sức khỏe cho Lao động trẻ”, ILO, 2018

[11] ILO và IFC, báo cáo tuân thủ lần thứ $10, \mathrm{ILO}, 2019$

[12] ILO và IFC, báo cáo tuân thủ lần thứ 9 , ILO, 2017

[13] Phạm Trọng Nghĩa, Pháp luật về lao động trong quá trình toàn cầu hóa, 2009

[14] Nguyễn Thị Minh Nhàn, Quản trị thực hành trách nhiệm xã hội, NXB Đại học Quốc gia Hà Nội, 2019

[15] Viện khoa học lao động và xã hội, "Tác động của các hiệp định thuơng mai tư do thế hệ móni đến vấn đề lao động, việc làm ở Việt Nam", Viện khoa học lao động và xã hội, 2019.

[16] Fanning, Fred E, Basic Safety Administration: A Handbook for the New Safety Specialist, Chicago: American Society of Safety Engineers, 2003

[17] Benjamin O. Alli (2008), fundamental principle of OSH, ILO

[18] Ron Dotson at el., Principles of Occupational Safety Management, Cognella Academic, 2017

[19] Đặng Đình Đào, Giáo trình An toàn và vệ sinh lao động, NXB Đại học kinh tế quốc dân, 2015

[20] Lê Thị Thu Hiền (2017), “đặc điểm lao động và một số giải pháp nâng cao chất lượng lao động ngành dệt may", Hue University 